\title{
EL INSTRUMENTO COLECTIVO EN LA REFORMA LABORAL DE 2016
}

\author{
THE COLLECTIVE INSTRUMENT IN THE 2016 LABOR \\ REFORM
}

\author{
PEDRO IRURETA URIARTE* \\ Universidad Alberto Hurtado
}

\begin{abstract}
RESUMEN: La reforma laboral introducida por la Ley $\mathrm{N}^{\circ} 20.940$ (2016), rediseñó la figura del instrumento colectivo. Tomando normas que ya estaban en el Código del Trabajo anterior a la reforma, y agregando algunas variantes legislativas, la nueva normativa posicionó al instrumento colectivo dentro de un concepto amplio y genérico debajo del cual caben distintas alternativas tales como el contrato colectivo, el convenio colectivo o el fallo arbitral. Los requisitos y exigencias que la reforma incorpora, exigen desentrañar el alcance del instrumento colectivo, resolviendo los vacíos que la nueva legislación ha generado. Sin embargo, dentro de este esquema, la figura del acuerdo del grupo negociador ha quedado en una evidente orfandad normativa, aun cuando la reforma se refiere a él en distintos pasajes.
\end{abstract}

PALABRAS CLAVE: Negociación colectiva; instrumento colectivo; fuentes del Derecho del Trabajo

ABSTRACT: The labor reform introduced by Law No. 20,940 (2016) redesigned the figure of the collective instrument. Taking the norms already in the Labor Code prior to the reform, and adding some legislative variants, the new regulation placed the collective instrument within a broad and generic concept under different alternatives such as the collective agreement or arbitration decision. The requirements that the reform incorporates demand to unravel the scope of the collective instrument, solving the legal gaps that the new legislation has generated. However, within this scheme, the figure of the negotiating group's agreement has been left in an obvious normative loneliness, even though the reform refers to it in different passages.

KEYWORDS: Collective bargaining; collective instrument; sources of Labor Law

\section{INTRODUCCION}

Todo ordenamiento jurídico requiere establecer con claridad su sistema de fuentes. Dicho sistema le permite explicar el origen de los poderes normativos y el alcance de ciertas instituciones nucleares. Lo mismo ocurre en el caso particular de cada disciplina jurídica, en que las fuentes hacen posible comprender la manera en que se producen las normas respectivas, así como el alcance jerárquico de ellas.

A diferencia de lo que ocurre en otras ramas del ordenamiento jurídico, en el Derecho del Trabajo cohabita una distinta variedad de poderes normativos que dejan en evidencia una pluralidad representada por las fuentes estatales, por la autonomía colectiva y por el poder normativo de las colectividades laborales inorgánicas o informales que dan origen a la costumbre laboral (Palomeque y Álvarez, 1995: 127) (Sempere, 1983: 70). Lo anterior representa una peculiaridad muy propia del Derecho del Trabajo, toda vez que en su sistema normativo existen dos tipos de reglas jurídicas: aquellas compartidas con los restantes sectores del ordenamiento jurídico y aquellas propias de esta disciplina, como es el caso del instrumento colectivo (Montoya Melgar,

\footnotetext{
* Abogado y Licenciado en Derecho por la Pontificia Universidad Católica de Chile. Doctor en Derecho por la Universidad Complutense de Madrid. Profesor Titular de Derecho del Trabajo de la Universidad Alberto Hurtado. Correo electrónico: piruret@uahurtado.cl

Este trabajo fue recibido el 14 de diciembre de 2016 y aprobado el 26 de diciembre de 2016.
} 
2008: 82) ${ }^{1}$. Esas fuentes propias y específicas le permiten al ordenamiento laboral modalizar su configuración (Alonso Olea, 1982: 13 y 14), adecuarse a la realidad social y superar el simple esquema binario de fuentes (ley y reglamento) muy propio del Estado liberal legislativo (Cascajo Castro, 1988: 38), asumiendo una clara opción por el denominado pluralismo jurídico.

En el entramado propio del ordenamiento laboral, las fuentes estatales representan un sistema jerárquicamente superior a otros poderes normativos. En la configuración general del sistema de fuentes, el Estado tiene la atribución de establecer un marco mínimo dentro del cual deben desarrollarse las relaciones laborales, evidenciando un orden público de derechos y obligaciones a los cuáles están obligados los sujetos del contrato de trabajo. La circunstancia de que el Estado estructure un marco mínimo de ejecución de las relaciones laborales, no impide que otros órdenes normativos se integren en una función eminentemente complementaria, que permita mejorar el nivel básico que han trazado las fuentes estatales. Pero su integración se verifica, entre otros factores, por el hecho de que las fuentes estatales le reconocen valor a estos poderes normativos y legitiman las normas que ellos producen.

El instrumento colectivo, en su variada tipología, constituye una clara fuente del Derecho del Trabajo (Persiani, 2016: 103) (Mazzotta, 2016: 102). Sus cláusulas de carácter normativo tienen un evidente efecto de automaticidad (Kahn Freund, 1987: 234), tal como lo dispone el inciso segundo del nuevo artículo $311^{2}$; y un efecto de imperatividad, en el sentido que las "estipulaciones de un contrato individual de trabajo no podrán significar disminución de las remuneraciones, beneficios y derechos que correspondan al trabajador por aplicación del instrumento colectivo por el que esté regido"3. La imperatividad del instrumento colectivo se encuentra complementada, en todo caso, por la inderogabilidad in pejus; es decir, la inderogabilidad no es absoluta y el trabajador respectivo puede pactar cláusulas distintas a las colectivas siempre que sean más favorables. "En esta última situación no opera la imperatividad y permanece inalterable la autonomía privada individual de las partes del contrato de trabajo"4.

La reforma laboral introducida por la Ley $\mathrm{N}^{\circ} 20.940^{5}$ reguló, dentro de sus normas, la figura del instrumento colectivo. Lo hizo de manera amplia y genérica, admitiendo detrás de esta fuente un conjunto de alternativas representadas fundamentalmente por el contrato colectivo, el convenio colectivo, el fallo arbitral e, incluso, el acuerdo del grupo negociador. En este orden de ideas, la regulación del instrumento colectivo genera derechos y obligaciones dentro de las distintas modalidades de negociación colectiva; pero ello ha dejado abierta una serie de interrogantes vinculadas a su naturaleza, al alcance de su tipología y a los efectos que se derivan de este instrumento. El presente artículo busca responder parte de esas interrogantes, especificando los contornos de cada una de las figuras involucradas.

\footnotetext{
${ }^{1}$ Agrega: "En el Derecho del Trabajo sí existe una teoría propia de las fuentes, esto es, de los poderes normativos y de las normas de ellos emanadas".

${ }^{2}$ El mencionado precepto indica: "Las estipulaciones de los instrumentos colectivos reemplazarán en lo pertinente a las contenidas en los contratos individuales de los trabajadores que sean parte de aquellos".

${ }^{3}$ Vid., el nuevo artículo 311, inciso primero.

${ }^{4} \mathrm{Cfr}$. sentencia de la CORTE SUPREMA de 29 de enero de 2016 (Causa Ingreso Corte $\mathrm{N}^{\circ}$ 3409-2015). Un análisis más detallado de esta temática, en ROJAS MIÑO, Irene, "La negociación colectiva en Chile: la legal y la general". La negociación colectiva en Chile. Coordinación de Irene Rojas Miño. Librotecnia, Santiago 2014, pp. 117 y siguientes.

${ }^{5}$ Ley $\mathrm{N}^{\circ} 20.940$, que moderniza el sistema de relaciones laborales. Diario Oficial de 08 de septiembre de 2016.
} 


\section{LA CONFIGURACION DEL INSTRUMENTO COLECTIVO}

\section{La denominación introducida por la Ley $N^{\circ} 20.940$}

Desde una perspectiva meramente lingüística, la reforma laboral ha incorporado un concepto más amplio y homogéneo que el que ocupaba el antiguo Código del Trabajo. Ahora se habla de instrumento colectivo como un modo de graficar la convención que se celebra entre empleadores y trabajadores con el objeto de establecer condiciones comunes de trabajo y remuneraciones $u$ otros beneficios en especie o en dinero, por un tiempo determinado, de conformidad a las reglas previstas en el nuevo Libro IV del Código.

La expresión instrumento colectivo ya era utilizada por algunas normas de la legislación anterior a la reforma (Rojas Miño, 2007: 209) (Gamonal, 2007: 308), pero habrá que reconocer que la mayor parte de las referencias legales optaban por términos más específicos -tales como contrato o convenio colectivo- para referirse a esta particular fuente del Derecho del Trabajo. Tanto es así, que el artículo $6^{\circ}$ del Código laboral mantuvo sólo la definición de contrato colectivo como aquél "celebrado por uno o más empleadores con una o más organizaciones sindicales o con trabajadores que se unan para negociar colectivamente, o con unos y otros, con el objeto de establecer condiciones comunes de trabajo y de remuneraciones por un tiempo determinado", omitiendo un concepto más concreto del instrumento colectivo propiamente tal ${ }^{6}$.

Como se ha dicho, la normativa actual configura al instrumento colectivo, al menos lingüísticamente, como una expresión amplia y omnicomprensiva de distintas figuras que reflejan el resultado final de un proceso de negociación colectiva. Así, por ejemplo, el artículo 320 del nuevo Código indica que el "instrumento colectivo es la convención celebrada entre empleadores y trabajadores con el objeto de establecer condiciones comunes de trabajo y remuneraciones $\mathrm{u}$ otros beneficios en especie o en dinero, por un tiempo determinado, de conformidad a las reglas previstas en este Libro". Y agrega: "El laudo o fallo arbitral dictado según las normas de los artículos 385 y siguientes de este Código también constituye un instrumento colectivo". De este modo, detrás del término legal se ampara un cortejo de alternativas representadas por el contrato colectivo, el convenio colectivo, el fallo arbitral e, incluso, el acuerdo del grupo negociador.

Como señala Aylwin, esta tipología no agota las diversas manifestaciones de la autonomía colectiva, pudiendo existir otro tipo de alternativas que cuadren $o$ complementen la figura de un instrumento colectivo. "Nos referimos a diversas formas de expresión que adquiere el acuerdo de voluntades y bajo diversas denominaciones, tales como actas de acuerdo, protocolos, acuerdos marco, actas de reuniones y otras" (Aylwin Chiorrini: 71). A pesar de ello, parte de la doctrina y la misma jurisprudencia le han negado el carácter de instrumento colectivo a figuras tales como el "protocolo de acuerdo" o el "acuerdo marco" (Lizama Portal, 2016: 115)7, asumiendo que el concepto

\footnotetext{
${ }^{6}$ En el Código del Trabajo anterior a la reforma laboral, los artículos 66 bis, 145-I, 152-F, 256, 346, 351, 357, 381, 507 y 508, ya utilizaban la expresión instrumento colectivo. Referencias similares, aunque más escasas, también podían encontrarse en los artículos 257 y 325 del Código del Trabajo de 1987, o en los artículos 45, 122, 127, 133, y 157 de la Ley No 19.069. No obstante, todas esas referencias eran acotadas, sin que existiera una clara definición de este vocablo (como sí ocurría con la figura del contrato colectivo o del convenio colectivo). Además, no se trataba de un término usualmente ocupado por el legislador y su alcance quedaba en muchos casos abierto.

7 “No son instrumentos colectivos el 'protocolo de acuerdo' (dictamen N³897/58, de 01.09.2010) ni el ‘acuerdo marco' (dictamen N`214/4, 15.01.2009), al no cumplir los requisitos que el legislador nacional reconoce a todo instrumento para ser calificado como convenio colectivo". A nivel jurisprudencial, vid.
} 
y alcance de la expresión instrumento colectivo se encuentra circunscrita a las fórmulas legales rigurosamente establecidas en el Código del Trabajo.

Con todo, el nuevo artículo 320 obliga a concluir que entre el instrumento colectivo y el contrato o convenio colectivo, o el fallo arbitral, se produce una relación de género a especie, alzándose la primera de las expresiones indicadas como un concepto lo suficientemente amplio para cobijar dentro de sí distintas sub clases de autonomía colectiva. Tradicionalmente, el contrato colectivo era configurado como un acuerdo derivado del proceso de negociación colectiva reglada y, por tanto, sujeto a todos los procedimientos, plazos y etapas que exigía el Código del Trabajo. El Convenio, por su parte, se estructuraba como un acuerdo entre un empleador y dos o más trabajadores, en que fijan normas comunes de remuneraciones y demás beneficios propios de la contratación colectiva sin sujetarse al procedimiento de negociación reglada (Thayer, Novoa, 1987: 484). Y el propio legislador, desde antaño, ha venido incorporando dentro de esta tipología la figura del fallo arbitral.

En este orden de ideas, la nueva legislación mantiene las nomenclaturas de contrato y convenio colectivo, y las sumerge conjuntamente con el laudo arbitral en la genérica referencia del instrumento colectivo. Ello permite superar, en parte, las antiguas críticas que se formulaban sobre el término "contrato colectivo", toda vez que su objetivo no es un compromiso de prestación de servicios (como sí ocurre con el contrato individual), sino que un mecanismo de reglamentación de las condiciones en que se prestarán esos servicios ${ }^{8}$.

En materia de denominación, sólo resta agregar que, en distintos preceptos no sistematizados, la nueva legislación ha incorporado la idea referida al acuerdo de grupo negociador. Se trata de un término nuevo, carente de regulación específica, y con pretensiones de ser considerado como una clase más de instrumento colectivo ${ }^{9}$.

\section{La naturaleza del instrumento colectivo}

De conformidad con el propio inciso final del nuevo artículo 320 del Código, los instrumentos colectivos deberán constar por escrito y registrarse en la Inspección del Trabajo dentro de los cinco días siguientes a su suscripción. Es decir, se trata de un "pacto documentado por escrito, y sometido normalmente a una condiciones de elaboración prefijadas por la ley" (Montoya Melgar, 2008: 150). A partir de allí, la pregunta sobre su naturaleza obliga a despejar algunas interrogantes sobre el carácter de esta figura.

En primer lugar, el instrumento colectivo adquiere una naturaleza dual. En efecto, por una parte se encuadra dentro de los moldes contractuales privatísticos; y, al mismo tiempo, ostenta una clara función normativa en el sentido que actúa desde fuera de la relación individual (Alonso Olea y Casas Bahamonde, 2009: 1106). En este orden de ideas, no cabe duda que el instrumento colectivo se estructura de manera singular y

además, sentencia de la CORTE SUPREMA de 21 de julio de 2016 (Causa Ingreso Corte $\mathrm{N}^{\circ}$ 376702015); y de 29 de enero de 2016 (Causa Ingreso Corte $N^{\circ} 3409-2015$ ).

8 Cfr., THAYER ARTEGA, Sindicatos y negociación colectiva. Editorial Jurídica de Chile, Santiago 1991, p. 193. Vid. también MONTOYA MELGAR, cit., p. 153: “(...) a diferencia de la finalidad del contrato individual de trabajo (dicho grosso modo, el cambio de trabajo por salario), el convenio colectivo tiene por fin el establecimiento de las condiciones a las que han de someterse los contratos individuales". ${ }^{9}$ No obstante lo anterior, el legislador laboral ya había utilizado con anterioridad la referencia lingüística de "grupo negociador". Así se puede observar en los artículos 12, 22 y 15 transitorio del Decreto Ley No 2.758 (de 1979); en los artículos 291, 306 y 10 transitorio del Código del Trabajo de 1987; y en los artículos 102 y 156 de la Ley No 19.069. Lo mismo ocurría en los artículos 315, 327 y 380 del Código del Trabajo anterior a la reforma laboral de 2016. 
sui generis, con un valor jurídico que sobrepasa una mera condición contractual ${ }^{10}$. Más aun, el instrumento colectivo adquiere un carácter atípico, en razón de la variedad de obligaciones que deben asumir los intervinientes, así como por el carácter y representación que ostenta (Alonso Olea y Casas Bahamonde, 2009: 1022).

Tampoco cabe duda que los instrumentos colectivos deben celebrarse bajo ciertas formalidades y exigencias que lo apartan de una figura meramente consensual. No hay que olvidar que el artículo 320 vincula el concepto de instrumento colectivo a la necesaria escrituración y registro del mismo, sin perjuicio de que su celebración deberá llevarse a cabo "de conformidad a las reglas previstas en este Libro" (IV, sobre negociación colectiva). Esas formalidades consiguen evitar disputas posteriores sobre el contenido del acuerdo (Despax, 1989: 336), y permiten concluir que las cláusulas del instrumento gozan de presunción de legalidad hasta que no sean impugnadas judicialmente (Alonso Olea y Casas Bahamonde, 2009: 1105).

A partir de allí, podría sostenerse que el instrumento colectivo requiere de solemnidades que son irrenunciables para las partes. Y, por cierto, el contrato colectivo o el laudo arbitral -como sub especie de instrumento colectivo-, responden muy bien a esa lógica, la cual ha encontrado variado respaldo jurisprudencial ${ }^{11} \mathrm{y}$ dogmático (Machiavello Contreras, 1989: 393). Es decir, la figura del contrato colectivo y del fallo arbitral, como sub especies de un instrumento colectivo, obligan a que en su celebración se cumplan etapas, plazos y formas esenciales para que el acto en cuestión adquiera existencia. Y de allí deriva claramente su carácter solemne.

La conclusión anterior resulta más discutible en el caso del convenio colectivo y del acuerdo del grupo negociador, los cuales han quedado formalmente sin definición en el nuevo entramado normativo (Arellano, Liendo y Walker, 2016: 103). El convenio colectivo puede surgir de dos fuentes claramente diferenciadas: la negociación colectiva no reglada o la negociación colectiva de los trabajadores eventuales, de temporada y de obra o faena transitoria. En el primer caso, el nuevo artículo 314 del Código del Trabajo permite la denominada negociación colectiva no reglada; es decir, aquella de carácter voluntario, que se realiza en cualquier momento, de forma directa y sin restricciones de ninguna naturaleza. Este tipo de negociación se lleva a cabo sin sujeción a normas de procedimiento, y con el único objeto de convenir condiciones comunes de trabajo y remuneraciones, por un tiempo determinado. La misma lógica sigue el nuevo artículo 365, el cual permite la negociación colectiva de los trabajadores eventuales, de temporada y de obra o faena transitoria, de acuerdo a las reglas de la negociación no reglada (art. 314) o bien de acuerdo a las normas del capítulo II del Libro IV del Código del Trabajo ${ }^{12}$. En este último caso, el resultado de la negociación dará origen a un convenio colectivo solemne en el caso que la negociación se realice conforme al procedimiento indicado en los artículos 365 y siguientes. En los demás casos, y admitiendo que el convenio constituye un sub tipo de instrumento colectivo,

\footnotetext{
${ }^{10}$ STCo. de 09 de mayo de 2016. Rol No 3016-2016 (3026 CPT Acumulados), p. 105. En www.tribunalconstitucional.cl. Vid., también, KAHN-FREUND, cit., pp.223 y siguientes.

${ }^{11}$ Cfr., por todas, sentencia de la CORTE DE APELACIONES DE SANTIAGO de 16 de abril de 2014 $\left(\mathrm{N}^{\circ}\right.$ de Ingreso Corte 1645-2013); y sentencia de la CORTE SUPREMA de 14 de octubre de $2013\left(\mathrm{~N}^{\circ}\right.$ de Ingreso Corte 4187-2013). En el plano doctrinal, vid. además YAÑEZ MONJE, Eduardo, "Unifica jurisprudencia en el sentido que 'los permisos sindicales', en tanto se pretendan regulados de manera distinta -superior- a la establecida por la ley, deben corresponder, o ser producto de una negociación que conste por escrito' (Excma. Corte Suprema, Rol No 4.187-2013, de 14 de octubre de 2013)". Revista Chilena de Derecho del Trabajo Vol. 4, N 8 (2013), pp. 177 y siguientes.

${ }^{12} \mathrm{El}$ propio artículo 365 , inciso segundo, se encarga de aclarar que las "empresas estarán obligadas a negociar conforme al procedimiento regulado en este Capítulo (II del Libro IV) sólo en el caso que la obra o faena transitoria tenga una duración superior a doce meses".
} 
que debe escriturarse y registrarse, la duda que se plantea es si sus niveles de formalidad lo convierten en un acto solemne propiamente tal.

Una primera tesis, apoyada incluso por la jurisprudencia administrativa ${ }^{13}$ y la propia doctrina (Macchiavello Contreras, 1989: 394) (Gamonal, 2007: 313), concluye que la exigencia de escrituración es suficiente para concluir que el convenio colectivo es solemne. Sin la escrituración del documento, el instrumento no puede nacer a la vida del derecho y tampoco puede producir los efectos que le son propios. Es decir, se eleva la escrituración a un requisito de solemnidad. Asimismo, si no registrara el convenio sus cláusulas tendrían el carácter de un acuerdo fundado en la autonomía de los cuerpos intermedios, sin que los organismos fiscalizadores pudiesen asumir competencia para resolver cuestiones vinculadas a la interpretación del mismo.

Una segunda tesis, admitiendo que convenio y contrato colectivo son figuras diferentes, con fisonomía propia ${ }^{14}$, distingue entre requisitos de solemnidad y requisitos de formalidad. Como es sabido, un acto jurídico es solemne cuando el instrumento en cuestión está sujeto a una serie de exigencias especiales por expreso mandato de la ley, sin las cuales el acto no existe. Desde esta perspectiva, el convenio colectivo constituiría un acto formal, en que la voluntad debe expresarse por escrito y estar debidamente registrada. Y si no se cumplen con esas formalidades, el convenio adolece de nulidad relativa (si falta la escrituración) (Despax, 1989: 336) ${ }^{15}$ o bien no puede ser invocado por la parte interesada (en caso de no haberse registrado en la Dirección del Trabajo). Más aun, la exigencia de registro en la Inspección del Trabajo constituiría a juicio de esta segunda corriente una herramienta de mayor fiscalización, pero no de publicidad ni menos de solemnidad (ya que en caso contrario, cualquier persona podría tener acceso al contenido del instrumento colectivo). En síntesis, y siguiendo esta segunda tesis argumentativa, se trataría de un documento que sólo beneficia a las partes intervinientes, razón por la cual la falta de escrituración y registro podría ser saneada por las partes.

Con todo, habrá que reconocer que la tendencia jurisprudencial -salvo excepciones- ${ }^{16}$ se ha encaminado por reconocer la solemnidad del convenio colectivo por el sólo hecho de que el ordenamiento legal exija la escrituración y registro del mismo. Más aun, se parte de la base que en el Derecho Colectivo del Trabajo "la clave es la solemnidad" $"$. Por tanto, se produciría para estos efectos una asimilación entre convenio y contrato colectivo ${ }^{18}$, en el sentido que el convenio es solemne por la simple circunstancia de que su perfeccionamiento requiere de la escrituración y depósito en la Inspección del Trabajo (dentro de un plazo fatal de cinco días) ${ }^{19}$. Sin ese elemento

\footnotetext{
${ }^{13}$ Vid., por todos, dictamen $\mathrm{N}^{\circ} 7120 / 331$, de 07 de diciembre de 1992, de la Dirección del Trabajo.

${ }^{14}$ Cfr., sentencia de la CORTE DE APELACIONES DE SAN MIGUEL de 30 de abril de 1985. Gaceta Jurídica $\mathrm{N}^{\circ} 58$ (1985), p. 170.

${ }^{15}$ En esta lógica, la falta de escrituración no sería suficiente para comprometer la existencia del instrumento, a condición que exista un escrito posterior que concrete el acuerdo.

${ }^{16}$ Vid., por ejemplo, sentencia de la CORTE DE APELACIONES DE SANTIAGO de 27 de mayo de 2013 ( $\mathrm{N}^{\circ}$ de Ingreso Corte 1736-2012): “(...) en la especie no se trató de un contrato sino de un convenio colectivo, al que el artículo 351 del Código libera de las solemnidades del contrato colectivo, lo que desde luego reafirma el criterio que viene de explicitarse y que es el sustentado por el susodicho artículo 348 inciso primero"-

${ }^{17}$ Vid. sentencia de la CORTE DE APELACIONES DE SANTIAGO de 16 de abril de $2014\left(\mathrm{~N}^{\circ}\right.$ de Ingreso Corte 1645-2013).

${ }^{18}$ Cfr., sentencia de la CORTE DE APELACIONES DE ARICA de 12 de noviembre de 1993. Gaceta Jurídica $\mathrm{N}^{\circ} 161$ (1993), p. 124.

${ }^{19}$ De conformidad con el inciso final del artículo 320 de la Ley $\mathrm{N}^{\mathrm{o}} 20.940$, el registro de un instrumento colectivo debe realizarse "dentro de cinco días siguientes a su suscripción". Asimismo, el artículo 49 del Código Civil indica que "cuando se dice que un acto debe ejecutarse en o dentro de cierto plazo, se entenderá que vale si se ejecuta antes de la medianoche en que termina el último día del plazo".
} 
básico, no existiría convenio colectivo es los términos a que se refiere el Libro IV del Código del Trabajo. Además, la escrituración y el registro permiten resolver exigencias de seguridad jurídica, cuestión que se vincula con un mínimo principio de conocimiento de las normas y de control de su procedimiento de elaboración (Despax, 1989: 335).

La situación del acuerdo del grupo negociador se encuentra en un estadio distinto. Como se sabe, a partir de la Ley $\mathrm{N}^{\circ} 19.759$ (de 2001), las coaliciones transitorias de trabajadores sólo podían pactar a través de la negociación colectiva semi reglada. Dicho procedimiento exigía que el grupo estuviese formado por ocho o más trabajadores, y que existiera una comisión negociadora de no menos de tres ni más de cinco integrantes (elegida por los involucrados en votación secreta celebrada ante un Inspector del Trabajo). Además, el empleador estaba obligado a dar respuesta a la presentación hecha por los trabajadores dentro del plazo de 15 días; y la aprobación de la propuesta final debía ser realizada por los trabajadores involucrados en votación secreta celebrada ante un ministro de fe. Esta lógica de negociación colectiva semi reglada, con algunos cambios relevantes, fue mantenida por el proyecto inicialmente aprobado por el Congreso Nacional ${ }^{20}$. No obstante, en la nueva legislación y después del fallo del Tribunal Constitucional, no existe esta clase de normas y la negociación colectiva ha quedado reducida a dos tipos claramente diferenciados: negociación colectiva reglada ${ }^{21}$ y no reglada ${ }^{22}$.

Lo que ocurre, es que luego de la STCo. de 09 de mayo de 2016, los grupos negociadores quedaron teóricamente en igualdad de términos que los sindicatos para celebrar instrumentos colectivos (permitiendo lo que la doctrina ha denominado como el paralelismo organizacional al interior de una misma empresa) (Rojas Miño, 2014: 113). No obstante, y aun cuando la reforma laboral contiene diversas normas legales que se refieren a los grupos negociadores ${ }^{23}$, en la nueva legislación no existe una normativa específica que indique las formalidades y etapas que debe cumplir un instrumento celebrado por una coalición transitoria. Y lo anterior genera un vacío evidente al momento de especificar qué es un grupo negociador, y cuáles son los acuerdos que éste puede negociar (Arellano, Liendo y Walker, 2016: 103).

Por expresa aplicación del artículo 324, el acuerdo de grupo negociador constituye un instrumento colectivo, pero carece de regulación formal. Una primera

\footnotetext{
${ }^{20} \mathrm{El}$ artículo 315 del proyecto inicialmente aprobado por el Congreso regulaba la negociación colectiva semi reglada de las coaliciones transitorias, pero sólo en aquellas empresas en que no existía organización sindical. Las coaliciones en cuestión debían tener el mismo número de trabajadores que se exige para constituir sindicatos de empresa conforme al artículo 227, y los trabajadores serían representados por una comisión negociadora, conformada por no menos de tres integrantes ni más de cinco, elegida por los involucrados en votación secreta celebrada ante un Inspector del Trabajo. El empleador estaría obligado a dar respuesta a la presentación hecha por los trabajadores y la propuesta final del empleador tenía que ser aprobada ante el Inspector del Trabajo en votación secreta, por mayoría absoluta de los trabajadores involucrados. De esta manera, el documento suscrito de conformidad a esta modalidad de negociación se denominaba acuerdo de grupo negociador. Si se suscribiere un acuerdo sin sujeción a estas normas mínimas de procedimiento, este tendrá la naturaleza de contrato individual de trabajo para los involucrados y no producirá el efecto de un convenio colectivo".

${ }^{21}$ Artículos 327 y siguientes de la Ley $\mathrm{N}^{\circ} 20.940$.

${ }^{22}$ Artículo 314 de la Ley $\mathrm{N}^{\circ} 20.940$.

${ }^{23} \mathrm{Cfr}$., por ejemplo, y entre otros, el actual artículo 11 del Código del Trabajo (sobre modificaciones al contrato), el artículo 43 (sobre reajuste de remuneraciones), el artículo 82 (sobre el contrato de aprendizaje), el artículo 178 (sobre pactos de indemnización), y el mismo artículo 324 (sobre vigencia y duración de los instrumentos colectivos). Además, el inciso final del artículo 316 ha dejado establecido que el grupo negociador debe actuar a través de una comisión negociadora: "La comisión negociadora que represente a un grupo negociador tendrá derecho a solicitar al empleador la información específica para la negociación establecida en las letras a) y b) de este artículo, respecto de los trabajadores que represente y previa autorización de estos".
} 
tesis argumental conduce a sostener que, al no existir reglas legales específicas, entonces los grupos no pueden celebrar instrumentos colectivos. Se trataría de un derecho que requiere de desarrollo legal, y al no existir éste las partes estarían inhabilitadas para celebrar un instrumento de esta naturaleza. Este criterio no parece razonable, no sólo porque quebranta la decisión de la STCo. de 09 de mayo de 2016; además, llevaría a una conclusión ampliamente superada en el ámbito del Derecho constitucional: la tesis de que un derecho fundamental sólo podría hipotéticamente ejercerse en la medida que el legislador desarrolle su ejercicio ${ }^{24}$. A ello habría que agregar que, el propio Convenio $\mathrm{N}^{\circ} 154$ de la OIT le exige a los Estados que adopten las medidas adecuadas para fomentar la negociación colectiva, evitando alternativas que obstaculicen la libertad de negociación colectiva ${ }^{25}$.

Una segunda vía de solución para este silencio normativo, consistiría en aplicarle al acuerdo del grupo negociador las normas de la negociación colectiva reglada. Si esta última clase de negociación es la norma general, entonces tendría una aplicación supletoria para todas aquellas negociaciones colectivas que carecen de desarrollo legal. Esta alternativa también presenta reparos jurídicos. Lo cierto es que no existe ninguna norma en la Ley $\mathrm{N}^{\circ} 20.940$ que permita reconducir estos acuerdos a una negociación colectiva reglada. Por lo demás, si se utilizara esta alternativa lo cierto es que existirían una serie de normas del Título IV, Libro IV, del Código, que no se podrían aplicar en razón de la especial naturaleza que tiene una negociación colectiva ejecutada por un grupo negociador.

Un tercer camino sería el de concluir que, la negociación colectiva de los grupos transitorios de trabajadores se puede llevar a cabo con total desregulación. Así ocurría con anterioridad a la reforma de la Ley $\mathrm{N}^{\circ} 19.759$ (de 2001), en que las coaliciones transitorias pactaban mediante un procedimiento informal y flexible, sin exigencia de quórum, y sin obligación de negociar por parte del empleador. No obstante, en este escenario, el acuerdo del grupo negociador dejaría ser un instrumento colectivo propiamente tal para convertirse en un acto pluripersonal, una especie de "acto individual en serie que satisface intereses individuales a través de un documento único" (Macchiavello, 1989: 404). Por lo demás, y en atención a los reparos que suponía la desregulación, el ordenamiento jurídico chileno ya superó, en parte, esta etapa al dictarse la Ley $\mathrm{N}^{\circ} 19.759$ (de 2001). Este último cuerpo legal sometió la negociación colectiva de los grupos transitorios a determinados requisitos a fin de garantizar la existencia de una negociación y marginar la imposición por parte del empleador (Rojas Miño, 2007: 215). Esto es lo que se denominó negociación colectiva semi reglada.

Como se puede observar, las tres alternativas planteadas presentan serias dificultades en su aplicación. Por tanto, habrá que esperar a que la jurisprudencia, o eventualmente el legislador, resuelvan estas omisiones en lo que respecta a la negociación colectiva de las coaliciones transitorias de trabajadores.

\section{El contenido del instrumento colectivo}

La reforma laboral introducida por la Ley $\mathrm{N}^{0} 20.940$, se ha adelantado en enumerar las menciones que debe contener el instrumento colectivo. Se trata de una

\footnotetext{
${ }^{24}$ Este fue el criterio argumentativo que siguió, por lo demás, en relación con la huelga, la sentencia de la CORTE DE APELACIONES DE SANTIAGO de 23 de octubre de 2015 ( $\mathrm{N}^{\mathrm{o}}$ de Ingreso Corte 11442015. En www.poderjudicial.cl): “(...). La sola circunstancia que la ley regule la huelga para un caso, en la negociación colectiva reglada, no puede llevarnos a sostener que fuera de ella se encuentre prohibida, pues lo que el legislador ha omitido regular o definir, no puede sostenerse que lo ha prohibido. (...)".

${ }^{25} \mathrm{Cfr}$., artículos $5^{\circ}$ y $8^{\circ}$ del Convenio $\mathrm{N}^{\circ} 154$ de la OIT (a la fecha, no ratificado por Chile).
} 
enumeración muy similar a la establecida en el antiguo artículo 345 del Código del Trabajo, con la diferencia que dicha norma se estableció exclusivamente para el contrato colectivo. Ahora, la reforma ha hecho extensivo estos requisitos a las diversas modalidades de instrumento colectivo.

En esta enumeración, el nuevo texto legal ha dejado de lado la norma establecida en el antiguo artículo $345 \mathrm{~N}^{\circ} 2$ del Código, según la cual el contrato colectivo no podía válidamente contener estipulaciones que hicieran referencia a la existencia de otros beneficios o condiciones incluidos en contratos anteriores, sin entrar a especificarlos detalladamente. Esta última opción normativa se alejaba de la práctica utilizada por el Código de 1931 y tenía por objeto asegurar que un instrumento colectivo se bastara a sí mismo, sin necesidad de ser reenviado a otros instrumentos de fechas anteriores, que eventualmente podrían quedar subsistentes, asegurándose que el instrumento en cuestión contuviera "todos los beneficios de que gozan los trabajadores, los que deben estar expresamente señalados. No son exigibles si sólo constan en cláusulas que hacen referencia a beneficios incluidos en contratos anteriores sin especificarlos".

Dicho en una frase, el legislador anterior a la reforma partía de la base que el nuevo contrato colectivo sustituía completamente las estipulaciones del instrumento colectivo anterior, no resultando admisible el exigir beneficios en razón de instrumentos ya terminados y caducados por el transcurso del tiempo (salvo, por cierto, que se indicara expresamente lo contrario). Lo que parecía animar a dicho legislador era una aparente sujeción al principio de modernidad y de seguridad jurídica que obligaba a respetar la extinción de las cláusulas de los instrumentos colectivos en el entendido que sería imposible pretender que los contratos tuviesen, ya sea parcial o totalmente, una duración de carácter indefinida. Tampoco resultaba legalmente admisible, pues de conformidad con lo establecido en el artículo $345 \mathrm{~N}^{\circ} 3$ del anterior Código del Trabajo, las partes de un contrato colectivo debían imperativamente establecer el período de vigencia del instrumento y de sus estipulaciones particulares, señalando el término del mismo.

Pues bien, como ya se ha dicho, la reforma introducida por la Ley $\mathrm{N}^{\mathrm{o}} 20.940$ elimina la referencia contenida en el antiguo artículo $345 \mathrm{~N}^{\circ} 2$ y opta por exigir cláusulas mínimas, puntuales, a objeto que el instrumento colectivo deje abierta distintas alternativas de regulación derivadas del acuerdo de los sujetos contratantes.

\subsection{La partes intervinientes}

El nuevo artículo 321 del Código exige que el instrumento colectivo señale la "determinación precisa de las partes a quienes afecte". Como se sabe, uno de los temas que generó mayor controversia durante la tramitación de la reforma laboral decía relación con el sujeto habilitado para llevar a cabo la negociación colectiva en representación de los trabajadores. Inicialmente, la propuesta del Ejecutivo consagraba la denominada titularidad sindical, relegando la actuación del grupo negociador sólo a aquellas empresas en que no existiera sindicato. La sentencia del Tribunal Constitucional de 09 de mayo de $2016^{26}$, eliminó esta alternativa y terminó equiparando la negociación colectiva del sindicato y de los grupos negociadores.

En este escenario, la exigencia planteada por el artículo 321 (en relación con las menciones obligatorias) obliga a concluir que las partes intervinientes en un instrumento colectivo pueden ser tanto un sindicato como un grupo negociador (aun cuando, en este

\footnotetext{
${ }^{26}$ Sentencia del TCo. de 09 de mayo de 2016. Rol No 3016-2016 (3026 CPT Acumulados). En www.tribunalconstitucional.cl
} 
último caso, no existe en la nueva normativa un marco regulatorio expreso para su ejercicio).

La determinación precisa de las partes busca, a fin de cuentas, controlar la efectiva representatividad de los firmantes del instrumento (Goerlich Peset, 2013: 424). Además, pretende establecer con claridad a qué trabajadores les será aplicable el instrumento colectivo. Esto obliga a que el instrumento en cuestión tenga una nómina muy similar a la que debió haberse acompañado al momento de presentar el proyecto ${ }^{27}$, y que eventualmente pudo haber sido aumentada con trabajadores afiliados a un sindicato dentro de los cinco días de presentado el proyecto ${ }^{28}$. A este respecto, cabe hacer presente la STCo. de 09 de mayo de 2016 declaró inconstitucional el inciso primero del artículo 323 que preliminarmente había aprobado el Congreso Nacional. Dicho artículo señalaba que la "afiliación sindical otorgará de pleno derecho a los nuevos socios los beneficios del instrumento colectivo suscrito por la organización sindical a la que se incorporen, conforme a los requisitos establecidos en dicho instrumento, a partir de la comunicación de la afiliación al empleador". Pues bien, y a partir de la STCo., los socios incorporados al sindicato después de transcurridos cinco días de haberse presentado el proyecto, no son parte ni les afecta el instrumento colectivo.

Por último, y como resulta evidente, el instrumento colectivo debe ser debidamente firmado por las partes intervinientes. Este es un requisito esencial, ya que permite acreditar la autenticidad del acto y la obligatoriedad que implica para los sujetos contratantes (Despax, 1989: 336).

\subsection{Las normas sobre remuneraciones, beneficios, condiciones de trabajo y demás estipulaciones que se hayan acordado, y que hayan sido especificadas detalladamente}

Si bien la forma en que se escritura el instrumento colectivo es libre (Despax, 1989: 336), no cabe duda que núcleo de dicho instrumento se encuentra precisamente en la consagración de cláusulas que determinen remuneraciones, beneficios y condiciones de trabajo. En una lectura preliminar, podría concluirse que la reforma sólo incluye cuestiones que las legislaciones pretéritas también señalaban. En efecto, desde el Decreto Ley $\mathrm{N}^{\mathrm{o}} 2.758$ (de 1979) en adelante el legislador ha venido estableciendo que todo instrumento colectivo debe contener normas sobre remuneraciones, beneficios (en dinero) y condiciones de trabajo que se hayan acordado ${ }^{29}$. Las remuneraciones se vinculan con toda la estructura salarial; los beneficios, se relacionan con cualquier

\footnotetext{
${ }^{27} \mathrm{El}$ nuevo artículo 328 exige que, conjuntamente con la presentación del proyecto de contrato colectivo, se deberá acompañar "la nómina de los trabajadores que hasta ese momento se encuentren afiliados".

${ }^{28}$ Vid. artículo 331 de la Ley $\mathrm{N}^{\circ} 20.940$, según el cual una vez iniciado un proceso de negociación colectiva reglada, "los trabajadores no afiliados al sindicato tendrán derecho a afiliarse a él, incorporándose de pleno derecho a la negociación en curso, salvo lo dispuesto en el inciso segundo del artículo 323. Con todo, sólo se incorporarán a la negociación en curso los trabajadores que se afilien hasta el quinto día de presentado el proyecto de contrato colectivo". Como se puede apreciar, en el caso del contrato colectivo, la nueva legislación reafirma el criterio que sólo podrán participar trabajadores que se encuentren afiliados al sindicato (ya sea que se encontraban afiliados al momento de presentarse el proyecto, o bien que lo hicieron dentro de los cinco días siguientes a la presentación del proyecto). De este modo, la nueva legislación no incorpora la figura de los adherentes (antiguo artículo 323 del Código); y en su reemplazo sólo ha aceptado la participación del ex afiliado (actual artículo 323 de la Ley $\mathrm{N}^{\mathrm{o}}$ 20.940) o del trabajador que se beneficia con la extensión (artículo 322 de la Ley No 20.940).

${ }^{29}$ Cfr., artículo 31 del Decreto Ley N 2.758 (de 1979). La misma lógica siguió el artículo 316 del Código de 1987, el artículo 121 de la Ley $\mathrm{N}^{\circ} 19.069$ (aun cuando se hizo referencia sólo a los beneficios, eliminándose la expresión “en dinero"), y el artículo 345 del Código anterior a la reforma.
} 
provecho o ganancia que obtenga el trabajador (sea en dinero, en especies o en servicios); y las condiciones de trabajo deben ser asociadas, de acuerdo con los instrumentos de la OIT, con todas "aquellas condiciones derivadas de o conexas con los contratos de trabajo y su ejecución, en el más amplio sentido, 'las relaciones laborales en su conjunto'. Así, pueden ser, y son de hecho, objeto de negociación colectiva la seguridad y protección social complementarias, el empleo, las relaciones del empresario con el sindicato, o la formalización y resolución de conflictos" (Alonso Olea y Casas Bahamonde, 2009: 1024).

Con todo, la legislación actual, en apariencia muy similar a sus predecesoras, termina ampliando el ámbito regulatorio del instrumento colectivo. Ciertamente, este instrumento contendrá normas sobre remuneraciones, beneficios y condiciones de trabajo; pero además podrá contener todo tipo de estipulaciones debidamente acordadas, siempre y cuando se encuentren especificadas. En este orden de ideas, el nuevo Código abre las alternativas de los negociadores y les permite incorporar otro tipo de estipulaciones distintas de lo meramente remuneracional o de los beneficios y condiciones de trabajo. Y con ello se logra responder, en parte, a la amplitud de contenidos que la propia OIT ha indicado en su Convenio $\mathrm{N}^{\mathrm{0}} 154^{30}$.

Probablemente, el único límite que se cierne sobre estos acuerdos se encuentre vinculado a las materias de negociación. Es decir, las partes tendrán libertad para acordar estipulaciones de interés mutuo teniendo como telón de fondo todas aquellas materias de preocupación común que afecten las relaciones mutuas entre trabajadores y empleador, "especialmente las que se refieran a remuneraciones u otros beneficios en especie o en dinero y, en general, a las condiciones comunes de trabajo". Pero, dentro de estas estipulaciones, podrán contemplarse "acuerdos para la conciliación del trabajo con las responsabilidades familiares, el ejercicio de la corresponsabilidad parental, planes de igualdad de oportunidades y equidad de género en la empresa, acciones positivas para corregir situaciones de desigualdad, acuerdos para la capacitación y reconversión productiva de los trabajadores, constitución y mantenimiento de servicios de bienestar, mecanismos de solución de controversias, entre otros" ${ }^{31}$.

Por último, habrá que advertir que el texto legal exige que las estipulaciones del instrumento contengan una explicación por sí mismas, evitando declaraciones que carecen de individualidad. Dicho de otra manera, el contenido de las cláusulas debe detallarse expresamente, y no pueden ser de tal generalidad que resulte imposible caracterizarlas o distinguirlas.

\subsection{El plazo de duración}

Acercándose a un modelo más estático de negociación colectiva (Monereo Pérez y Tomás Jiménez, 2013: 68), el legislador laboral chileno ha venido acotando, progresivamente, el plazo de duración de los instrumentos colectivos. En efecto, la Ley No 19.069 (de 1991) sólo se limitaba a establecer un término mínimo de dos años para la vigencia del contrato en cuestión $^{32}$; pero dejaba abierta la posibilidad de que ese

\footnotetext{
${ }^{30} \mathrm{El}$ artículo $2^{\mathrm{o}}$ del Convenio $\mathrm{N}^{\mathrm{o}} 154$ de la OIT, incorpora dentro de las materias a negociar la fijación de las condiciones de trabajo y empleo; la regulación de las relaciones entre empleadores y trabajadores; y la regulación de las relaciones entre empleadores o sus organizaciones y una organización o varias organizaciones de trabajadores.

${ }^{31}$ Cfr., el nuevo artículo 306 introducido por la Ley $\mathrm{N}^{\circ} 20.940$.

${ }^{32}$ Cfr., artículo 123 de la Ley $\mathrm{N}^{\circ} 19.069$.
} 
instrumento se extendiera innecesariamente en el tiempo ${ }^{33}$. Para evitar esto, la Ley $\mathrm{N}^{\mathrm{o}}$ 19.759 (de 2001), circunscribió los plazos de vigencia entre dos y cuatro años. Según señaló la entonces Directora del Trabajo "por lo que se ha visto, en muchos casos, los plazos de vigencia de un contrato colectivo excesivamente prolongados, dan lugar a múltiples dificultades, y van contra la esencia de la institución" ${ }^{34}$. De allí que se considerara más razonable circunscribir los períodos mínimo y máximo de cobertura de un instrumento de esta naturaleza. Más aun, dicho rango de temporalidad permitía garantizar una cierta estabilidad de las condiciones pactadas, y evitar un instrumento de muy escasa duración (González Ortega, 2004: 140).

La reforma laboral avanzó en esta lógica. Por una parte, rebajó de cuatro a tres años la extensión temporal del instrumento colectivo entendido en su globalidad $^{35} ; \mathrm{y}$, por otra, reafirmó implícitamente el criterio de que el ejercicio regular de la negociación colectiva permitía confluir en instancias más idóneas de diálogo al interior de la empresa. A fin de cuentas, un plazo menor de duración máxima permite adecuar las estipulaciones acordadas para períodos en que la empresa podía eventualmente estar sujeta a condiciones económicas y comerciales distintas. De allí que un plazo máximo de 3 años se considerara más adecuado con la práctica laboral, permitiendo que las partes se adapten a los cambios que va experimentando la propia empresa, logrando la realización de evaluaciones constantes a objeto de determinar si las condiciones que previeron los contratantes para su ejecución efectivamente se cumplen ${ }^{36}$. Desde esta perspectiva, la nueva ley se limitó a establecer rangos de temporalidad mínima y máxima, dejando el juicio de oportunidad sobre la duración efectiva a las partes intervinientes. Lo anterior no impide, en todo caso, que los suscriptores del instrumento

\footnotetext{
${ }^{33}$ La doctrina de la época ya advertía las dificultades que traía consigo el no fijar plazos máximos de duración del instrumento colectivo. Así, por ejemplo, THAYER y NOVOA, cit., T. I, p. 432: "Por eso debe concluirse que el contrato colectivo puede durar más de dos años. Así, los sindicatos de la Compañía Minera El Indio celebraron un convenio colectivo por el período primero de septiembre de 1986 a 31 de julio de 1991 (...). Con todo, nos parecería contrario al espíritu de la legislación laboral un contrato colectivo que se conviniera, verbigracia, por diez o veinte años, estancando el fluir natural de las relaciones laborales".

${ }^{34}$ Cfr., BIBLIOTECA DEL CONGRESO NACIONAL, Historia fidedigna de la Ley $N^{o} 19.759$. Segundo Informe de la Comisión de Trabajo y Previsión Social. Diario de Sesiones del Senado, sesión $8^{a}$, especial, de 20 de junio de 2001, p. 786.

${ }^{35} \mathrm{El}$ mismo artículo 324 se encargó de distinguir la vigencia (período durante el cual se pueden ejercer los derechos y obligaciones) y la duración del instrumento colectivo (período que se relaciona con la fecha en que se extingue o vence el instrumento en cuestión). Para estos efectos, la norma del artículo 324 indica que la "vigencia de los contratos colectivos se contará a partir del día siguiente al de la fecha de vencimiento del contrato colectivo o fallo arbitral anterior. De no existir instrumento colectivo anterior, la vigencia se contará a partir del día siguiente al de su suscripción. Con todo, si se hubiere hecho efectiva la huelga, el contrato que se celebre con posterioridad o el fallo arbitral que se dicte, en su caso, sólo tendrán vigencia a contar de la fecha de suscripción del contrato, de constitución del compromiso o de la notificación de la resolución que ordena la reanudación de faenas, sin perjuicio de que su duración se cuente a partir del día siguiente al de la fecha de vencimiento del contrato colectivo o del fallo arbitral anterior, o del cuadragésimo quinto día contado desde la presentación del respectivo proyecto, según corresponda".

${ }^{36}$ Sobre el particular, vid. la intervención en el Senado del Subsecretario del Trabajo, señor Francisco Díaz Verdugo, quien "explicó que contratos colectivos del pasado duraban 8 años y luego el período se rebajó a 4 años, pareciendo adecuado y acorde con los tiempos fijar un máximo de 3 años, en sintonía con las dinámicas de los dirigentes de los sindicatos". BIBLIOTECA DEL CONGRESO NACIONAL, Historia de la Ley $N^{\circ}$ 20.940. Segundo trámite constitucional en el Senado, p. 131 (en www.bcn.cl). A mayor abundamiento, vid. también ROJAS MIÑO, "Las reformas laborales", cit., p. 216: una duración de hasta ocho años "niega uno de los objetivos del ejercicio de la autonomía colectiva: la capacidad de efectuar una regulación en conformidad a los nuevos desafíos que presente el contexto de las relaciones laborales".
} 
puedan prorrogar la vigencia del mismo tal como lo preceptúa el inciso tercero del artículo 348, o bien celebrar un contrato colectivo forzoso en los términos señalados en el artículo 342.

Esta regla de temporalidad se aplica tanto al contrato colectivo como a los acuerdos de grupo negociador y los fallos arbitrales; pero en el caso de los convenios colectivos, la nueva normativa establece la posibilidad de que éstos tengan la duración que las partes definan, "pero en ningún caso podrá ser superior a tres años"37. Es decir, el legislador opta por reglamentar el plazo mínimo y máximo de la mayor parte de los instrumentos colectivos estableciendo que los mismos tendrán una duración mínima de dos años y una máxima de tres años. No obstante, en el caso del convenio colectivo se incorpora una regla más flexible, autorizando que el plazo mínimo de duración de dichos convenios sea inferior a dos años (no obstante, su duración máxima en caso alguno podrá sobrepasar los tres años de vigencia). Desde esta perspectiva, nada impediría que las partes intervinientes celebren un convenio de duración muy reducida o que, incluso, se agote de forma inmediata ${ }^{38}$.

Siguiendo la lógica que inicialmente tenía el proyecto presentado por el Ejecutivo, la ley hace una distinción entre "convenio colectivo" y "acuerdo de grupo negociador". Este último instrumento perentoriamente deberá tener la misma duración mínima y máxima que un contrato colectivo; pero el convenio, como se ha dicho, tiene flexibilidad temporal pudiendo pactarse por un período inferior a dos años. Claramente, en este caso, la nueva ley está haciendo referencia al convenio suscrito por un sindicato de conformidad con el artículo 314 del Código (o bien a aquél instrumento derivado de una negociación colectiva de trabajadores eventuales, de temporada y de obra o faena transitoria).

\subsection{Los acuerdos de extensión}

El Código del Trabajo anterior a la reforma, partía de una regla inicial: en materia de aplicación de un instrumento colectivo, éste sólo se aplica a los trabajadores que participaron de la respectiva negociación colectiva, salvo que el empleador hiciera uso de la facultad que establecía el derogado artículo 346 (referido a la extensión de beneficios). Desde esta perspectiva, el instrumento colectivo se construía como un acto jurídico que, de acuerdo a las normas generales, sólo afecta a aquellos que habían concurrido a su celebración, personalmente o representados (legal o convencionalmente) (López Santa María, 1986: 243).

\footnotetext{
${ }^{37} \mathrm{El}$ plazo de tres años como duración máxima parece ser una constante en toda la reforma laboral. Por ejemplo, en materia de pactos sobre condiciones especiales de trabajo, el inciso tercero del artículo 374 es perentorio en señalar que la "duración máxima de estos pactos será de tres años". Y en materia de jornada excepcional, el modificado inciso final del artículo 38 del Código señala ahora que la resolución del Director del Trabajo será por el plazo de "hasta tres" años. Como señaló la ministra Ximena Rincón en la Sala del Senado: "Con respecto a la norma que ahora nos ocupa, se pretende unificar los plazos de duración de las negociaciones colectivas, que son hasta tres años, con los pactos especiales, las autorizaciones de jornada especial del artículo 38, estableciendo permisos de hasta tres años (hoy día pueden ser de hasta cuatro)". Vid., BIBLIOTECA DEL CONGRESO NACIONAL, Historia de la Ley $N^{o}$ 20.940. Segundo trámite constitucional en el Senado, p. 1170 (en www.bcn.cl).

${ }^{38}$ En teoría, el establecimiento de límites mínimos y máximos de duración dejaría abierta la posibilidad para que, dentro de estos márgenes, el término del instrumento colectivo esté sujeto al "cumplimiento de ciertas condiciones ajenas al control de las mismas (cambio de titularidad de la empresa, alteración relevante de las circunstancias del mercado, pérdida o continuidad de determinados contratos o encargos, etc.)".
} 
En el nuevo diseño de negociación colectiva que se estructura en la Ley $\mathrm{N}^{\mathrm{o}}$ 20.940, la extensión de beneficios es el resultado de un acuerdo debidamente plasmado en el instrumento colectivo (González Ortega, 2004: 142) ${ }^{39}$. En razón de lo anterior, el nuevo artículo 322 del Código del Trabajo es perentorio en indicar que las "partes de un instrumento colectivo podrán acordar la aplicación general o parcial de sus estipulaciones a todos o parte de los trabajadores de la empresa o establecimiento de empresa sin afiliación sindical. En el caso antes señalado, para acceder a los beneficios dichos trabajadores deberán aceptar la extensión y obligarse a pagar todo o parte de la cuota ordinaria de la organización sindical, según lo establezca el acuerdo. El acuerdo de extensión (...) deberá fijar criterios objetivos, generales y no arbitrarios para extender los beneficios a trabajadores sin afiliación sindical" 40 .

El objetivo de este acuerdo de extensión es, desde luego, aportar al financiamiento de la entidad que obtuvo el beneficio; pero también termina consagrando un sano principio de ecuanimidad en atención a que algunos trabajadores se ven favorecidos con una negociación colectiva en la cual no participaron y en la que no soportaron ni sus costos ni sus riesgos (Ramaciotti Fracchia, 1992: 89). Por cierto, este reproche no se les puede formular a los trabajadores que durante la negociación colectiva en cuestión no pertenecían a la empresa; pero habrá que reconocer que la extensión unilateral del empleador, sin que mediara pacto, no favorecía la afiliación sindical (García Viña, 2013: 263).

\footnotetext{
${ }^{39}$ La figura de la extensión de los beneficios derivados de una negociación colectiva ya se encontraba consagrada en el Decreto Ley $\mathrm{N}^{\mathrm{o}} 2.758$ (de 1979). En efecto, y según lo establecido en el artículo 15 transitorio de dicho cuerpo legal "después de la primera negociación que se celebre en cada empresa en conformidad a esta ley, y por una sola vez, los trabajadores que no estuvieren sindicalizados y que no hubieren participado en un grupo negociador, y a los cuales sin embargo el empleador les hiciere extensivos todos o algunos de los beneficios acordados en el contrato o convenio colectivo o en el fallo arbitral, según el caso, deberán cotizar también por única vez al sindicato que hubiere obtenido los beneficios, una suma equivalente al monto de la cuota ordinaria sindical de dos meses". La orientación de esta norma fue recepcionada, con posterioridad y con algunos cambios, en el artículo 10 del Código del Trabajo de 1987: "Si en una empresa no se hubiera negociado colectivamente durante la vigencia del decreto ley $\mathrm{N}^{\circ} 2.758$, de 1979, y así se hiciere en conformidad al Código aprobado por esta ley, los trabajadores que no estuvieren sindicados y que no hubieran participado en un grupo negociador, y a los cuales, sin embargo, el empleador les hiciere extensivos todos o algunos de los beneficios acordados en el contrato o convenio colectivo o en el fallo arbitral, según el caso, deberán cotizar, por una sola vez, al sindicato que obtuviere los beneficios, una suma equivalente al monto de la cuota ordinaria de dos meses". Por último, y en una redacción que perduró hasta antes de la reforma laboral de 2016, el artículo 122 de la Ley No 19.069 reguló la extensión de beneficios disponiendo que los "trabajadores a quienes el empleador les hiciere extensivos los beneficios estipulados en el instrumento colectivo respectivo para los trabajadores que ocupen los mismos cargos o desempeñen similares funciones, deberán aportar al sindicato que hubiere obtenido los beneficios, un setenta y cinco por ciento de la cotización mensual ordinaria, durante toda la vigencia del contrato, a contar de la fecha en que éste se les aplique. Si éstos los hubiere obtenido más de un sindicato, el aporte irá a aquel que el trabajador indique". Si bien esta última normativa buscaba principalmente que los beneficiados contribuyeran al financiamiento de la cuota sindical, en la práctica la jurisprudencia le otorgó una dimensión tal -a este beneficio- que las figuras de extensión terminaron ocupando "el espacio de la autonomía colectiva, impidiendo que un trabajador cubierto por un instrumento colectivo pueda, con posterioridad, participar en una negociación colectiva" (vid. ROJAS MIÑO, "Las reformas laborales", cit., p. 214). A mayor abundamiento, vid. también HALPERN MONTECINO, Cecily, "Extensión de beneficios colectivos: La aplicación jurisprudencial del artículo 122 de la Ley No 19.069 y su posible efecto perverso". Revista Laboral Chilena $\mathrm{N}^{\circ} 10$ (1992), pp. 67 y siguientes; y RAMACIOTTI FRACCHIA, José Luis, "Extensión de beneficios a trabajadores que no negociaron colectivamente". Revista Laboral Chilena No 2 (1992), pp. 89 y siguientes.

${ }^{40}$ Quedan excluidas del acuerdo de extensión, y por tanto el empleador puede otorgar estos beneficios a otros trabajadores, "las cláusulas pactadas de reajuste de remuneraciones conforme a la variación del Índice de Precios al Consumidor determinado por el Instituto Nacional de Estadísticas o el que haga sus veces, siempre que dicho reajuste se haya contemplado en su respuesta al proyecto de contrato colectivo".
} 
El acuerdo de extensión se encuentra a mitad de camino entre la eficacia limitada del instrumento colectivo y la eficacia general o erga omnes. Y en esta dinámica, resulta esencial que cada instrumento colectivo exprese el acuerdo que, para cada negociación, obtuvieron las partes intervinientes. No sólo eso, la ley actual también exige la plasmación de una eventual falta de acuerdo, ya que lo que le interesa al legislador es que no quepa duda sobre la posibilidad de extender o no los beneficios que se han alcanzado en un determinado proceso negociador.

El acuerdo de extensión, debidamente regulado en el instrumento colectivo, tiene algunas particularidades que son imposibles de soslayar. En primer término, "transforma la extensión de beneficios en un asunto propio del contenido de la negociación colectiva y, por tanto, sometido al acuerdo entre empleador y el sindicato debiendo realizarse una explícita mención del acuerdo de extensión o de su imposibilidad" 41 . En segundo lugar, la nueva propuesta deja abierto el monto a pagar por concepto de la cuota sindical; no hay un guarismo o porcentaje específico. El único límite en el monto, es que éste no puede sobrepasar el valor total de la cotización sindical ya que la ley circunscribe el aporte a todo o a una parte de dicha cuota ${ }^{42}$. En tercer término, se trata de un acuerdo que puede tener el carácter de total o parcial (tanto en lo que se refiere a sus estipulaciones como a las personas beneficiadas); cuestión que supone un cambio en relación con la figura que consagraba el antiguo artículo 346 del Código, ya que de acuerdo a ese pretérito diseño para que existiera extensión se requería que los beneficios extendidos fuesen de una entidad tal que justificara el aporte del $75 \%$ de la cuota sindical ${ }^{43}$. Más aun, la misma jurisprudencia había refrendado la tesis de que la extensión debía referirse a beneficios de cierta entidad, no bastando la extensión de meros aspectos accidentales o simplemente formales del contrato colectivo ${ }^{44}$. Por el contrario, en el diseño de la Ley $\mathrm{N}^{\circ} 20.940$, el aporte parcial no sólo se refiere a la extensión acotada de beneficios; también sería factible mediante la extensión reducida de un beneficio en particular. Por tanto, la reforma parece indicar que poco importa para

\footnotetext{
${ }^{41}$ Vid. STCo. de 09 de mayo de 2016. Rol No 3016-2016 (3026 CPT Acumulados), p. 107. En www.tribunalconstitucional.cl. Por ello, y entre otras razones, la misma STCo. declaró inconstitucional la norma contenida en el inciso primero del artículo 323 inicialmente aprobado. Como se ha dicho, este precepto indicaba que la "afiliación sindical otorgará de pleno derecho a los nuevos socios los beneficios del instrumento colectivo suscrito por la organización sindical a la que se incorporen (...)".

${ }^{42}$ En este sentido, la norma recién aprobada se asemeja más a aquella que se contenía en el Mensaje Presidencial que dio origen a la Ley $\mathrm{N}^{\circ} 19.069$ (de 1991). Dicha propuesta señalaba que, en caso de extensión, el trabajador beneficiado debía pagar "una contribución al sindicato que ha negociado, fijada en los estatutos, pero nunca mayor a la cuota ordinaria durante el lapso de vigencia del instrumento colectivo". Vid. BIBLIOTECA DEL CONGRESO NACIONAL DE CHILE. Historia de la Ley $N^{o}$ 19.069 (en www.bcn.cl).

${ }^{43} \mathrm{La}$ redacción actual resuelve una antigua disputa jurisprudencial y dogmática, en orden a que el pago del $75 \%$ de la cuota sindical debía tener su origen en una extensión cualitativamente relevante. Vid. por ejemplo dictamen $\mathrm{N}^{\circ} 5028 / 224$, de 4 de septiembre de 1996, de la Dirección del Trabajo: "Los trabajadores por los cuales se consulta se encontrarán obligados a efectuar el aporte previsto en el inciso $1^{\circ}$ del artículo 346 del Código del Trabajo, sólo en el evento de que la extensión de beneficios contemplados en el respectivo contrato colectivo represente para ellos un incremento real y efectivo de sus remuneraciones y condiciones de trabajo"; o la sentencia de la CORTE SUPREMA de 17 de octubre de 2000 (Revista de Derecho y Jurisprudencia y Gaceta de los Tribunales, Tomo XCVII, sección tercera, 2000, p. 189) que dictaminó lo siguiente: "Las ventajas que el empleador hace extensivas a trabajadores no sindicalizados deben importar un aumento significativo y real de las condiciones de trabajo a objeto de acarrear la respectiva contribución de los beneficiados por ellas y que no participaron en la negociación colectiva, y no, como en la especie, en que el empleador demandado les ha extendido sólo un beneficio: el de la gratificación bimensual anticipada y reajustable, el que tiene su fuente en la ley y a cuyo pago el demandado se encontraría igualmente obligado".

${ }^{44}$ Cfr., sentencia de la CORTE SUPREMA de 17 de octubre de 2000. Revista de Derecho y Jurisprudencia y Gaceta de los Tribunales, Tomo XCVII, sección tercera (2000), p. 189.
} 
estos efectos si mediante la extensión se produjo o no un mejoramiento real y significativo de las condiciones de trabajo (Halpern Montecino, 1992: 69). En cuarto lugar, y a diferencia de lo que ocurría con la antigua normativa, ahora el legislador ha exigido que el acuerdo de extensión se realice con la aceptación explícita del beneficiado de forma tal que ya no puede ser extendido unilateralmente por alguna de las partes del instrumento colectivo ni tampoco puede deducirse de meras aceptaciones tácitas. La aceptación debe ser expresa y con indicación precisa del instrumento colectivo que se está extendiendo. Por ello, producida la aceptación formal no puede dejarse sin efecto el pacto ya que "el contrato colectivo es de las partes y no de una de ellas" 45 . Con todo, la aceptación del beneficiado debe ser pura y simple, como una especie de contrato de adhesión, ya que la norma no autoriza a realizar acuerdos particulares más allá del marco que las partes del instrumento colectivo ya acordaron.

Sin embargo, y en último término, la nueva normativa legal establece un límite en relación con acuerdos eventualmente discriminatorios. De allí que el artículo 322 indique que el pacto de extensión debe "fijar criterios objetivos, generales y no arbitrarios para extender los beneficios a trabajadores sin afiliación sindical". De este modo, la norma en comento debe ser interpretada como una interdicción de la arbitrariedad por parte de los sujetos que intervienen en la negociación colectiva. Lo que ocurre es que la especial posición que ocupan ambos intervinientes en el proceso negociador, obliga a concluir que se encuentran prohibidas todas aquellas actuaciones arbitrarias, contrarias a la justicia y al derecho, en materia de acuerdos de extensión, de modo tal que el pacto debe ostentar una fundamentación objetiva que impida "el ejercicio de decisiones unilaterales que afecten el modo en que se identifican a los beneficiarios" $" 46$.

Adicionalmente, el pacto de extensión no puede ser visto como un atributo ejercido unilateralmente por una de las partes de un instrumento colectivo y obligatorio para el beneficiado. Muy por el contrario, la ley exige que "para acceder a los beneficios dichos trabajadores deberán aceptar la extensión y obligarse a pagar todo o parte de la cuota ordinaria de la organización sindical, según lo establezca el acuerdo". Como se ha dicho, esto supone un cambio radical con la normativa anterior, pues en el diseño que ocupaba el antiguo artículo 346 del Código el beneficiado con la extensión estaba obligado a aceptar la aplicación total o parcial del instrumento y, en consecuencia, no podía oponerse al pago del $75 \%$ de la cuota sindical.

Por último, la importancia que el legislador le ha otorgado a este pacto se ve reflejada en la configuración de un nuevo tipo de práctica antisindical, más preciso y fuertemente vinculado a la naturaleza misma de la infracción que se busca sancionar. En efecto, la nueva letra h) del artículo 289 considera como práctica antisindical el "otorgar o convenir con trabajadores no afiliados a la organización u organizaciones que los hubieren negociado, los mismos beneficios pactados en un instrumento colectivo".

De este nuevo tipo infraccional, se exceptúan dos figuras: (i) la excepción ya señalada del inciso final del artículo 322, en el sentido que el empleador puede aplicar libremente a todos los trabajadores de la empresa las cláusulas de reajustabilidad de remuneraciones conforme al IPC ("siempre que dicho reajuste se haya contemplado en

\footnotetext{
${ }^{45}$ STco. de 09 de mayo de 2016. Rol $\mathrm{N}^{\mathrm{o}}$ 3016-2016 (3026 CPT Acumulados), p. 112. En www.tribunalconstitucional.cl. Y la misma sentencia agrega en p. 114: "el contrato colectivo es fuente de derecho y el empleador no puede desconocer su alcance y fuerza normativa. (...). $21^{\circ}$. Que, por último, la libre iniciativa económica no aparece limitada en este proyecto de ley por las reglas propias del contrato colectivo por dos razones. Primero, porque al referirse a una negociación que es fruto de un acuerdo pactado de extensión, el resultado del mismo es una regla de orden público (...)”.

${ }^{46}$ STco. de 09 de mayo de 2016. Rol No 3016-2016 (3026 CPT Acumulados), p. 109. En www.tribunalconstitucional.cl
} 
su respuesta al proyecto de contrato colectivo"); y (ii) los acuerdos individuales que el empleador alcance con un trabajador "sobre sus remuneraciones o sus incrementos que se funden en las capacidades, calificaciones, idoneidad, responsabilidad o productividad del trabajador".

De estas dos excepciones, la que traerá mayores dificultades interpretativas es la referida a la existencia de una presunta práctica antisindical ${ }^{47}$. Esta interpretación, deberá transitar en base a dos objetivos que el texto legal intenta armonizar. Por una parte, resulta evidente que el legislador pretende evitar extensiones encubiertas; es decir, que por la vía del mejoramiento de remuneraciones se terminen obteniendo mejores beneficios que aquellos que consiguieron el sindicato o el grupo negociador. Pero por otra, la nueva norma legal centra el problema en la legitimidad que tienen los acuerdos individuales para establecer diferencias en la estructura salarial. Esto lleva a concluir que en el ámbito laboral no se aplica el principio de igualdad (pensado para las relaciones que mantiene el ciudadano con el Estado) sino que el principio de no discriminación arbitraria.

De esta manera, la nueva figura de práctica antisindical obliga a analizar la excepción legal en base a las circunstancias que concurren en cada sujeto concreto con respecto al cual se invoca (Palomeque, 2004: 95). En esta perspectiva, la nueva normativa sanciona el resultado discriminatorio; es decir, un hecho objetivo independiente de la intencionalidad del agente productor del mismo. Y a fin de evaluar dicho resultado, resulta esencial efectuar un examen de comparación, para luego analizar las causas de la eventual discriminación.

Como es ampliamente sabido, la no discriminación constituye una condición esencial tanto de la libertad de trabajo como de la libertad sindical. En consecuencia, resulta imposible configurar una libertad tan amplia sin que, a la vez, existan normas que resguarden efectivamente un interdecir de arbitrariedad en el acceso y desempeño del trabajo. Lo anterior obliga a separar conceptualmente las figuras del principio de igualdad y de la no discriminación (Starck, 2002: 62) (Rodríguez-Piñero, Bravo-Ferrer y Fernández López, 1986: 64 y 65) ${ }^{48}$. En rigor, el empleador no está estrictamente obligado a cumplir en toda su magnitud el principio de igualdad ante la ley, pensado como se ha dicho para los actos que ejecute el poder público (Martínez Rocamora, 1998: 119) ${ }^{49}$. Por el contrario, lo que pesa sobre el empleador es la interdicción de comportamientos discriminatorios, de modo tal que no pueda diferenciar desfavorablemente a un trabajador por elementos no vinculados a la capacidad o a la

\footnotetext{
${ }^{47}$ Artículo 289, letra h).

48 “(...) el principio general de igualdad constitucional, normalmente no tiene vigencia en el Derecho Privado, puesto que un deber de igualdad de trato dotado de validez general 'sacaría de quicio' al Derecho Privado"; y RODRIGUEZ-PIÑERO Y BRAVO-FERRER. Miguel, y FERNANDEZ LOPEZ, María Fernanda, Igualdad y Discriminación. Tecnos, Madrid, 1986, pp. 64 y 65: “(...) el principio de no discriminación 'no es la simple consecuencia de la igualdad sino una aplicación modulada y dinámica de ésta' (...). La utilización de este término (...) no es una simple especificación del principio, sino un mandato especial que, aun cuando derivado del principio de igualdad, va más lejos, y dice algo distinto del mandato de igual protección en el marco de la ley". Y estos últimos autores agregan en p. 263: "El principio de igualdad 'en y ante' la ley sí es susceptible de ser interpretado en clave de relaciones ciudadano-Estado, porque en ellas agota su función básica. Pero no ocurre lo mismo con la no discriminación: ésta no es sólo un área de libertad que garantiza a su sujeto titular frente al Estado".

49 “(...) el principio general de igualdad, en sí mismo, como principio constitucional, se agota en la relación ciudadano-Estado”. Y agrega en pp. 136 y 137: “(...) la división fundamental entre 'prohibición discriminatoria' y 'principio general de igualdad'. La primera tiene virtualidad aplicativa plena por sí misma, al derivar de la Constitución, no estando necesitada del apoyo de ningún criterio igualatorio de refuerzo, mientras que el principio general, por el contrario, sólo será de aplicación si así se establece en concreto, para el caso particular, en el ordenamiento jurídico".
} 
idoneidad. Un criterio distinto llevaría a prohibir el otorgamiento, por ser inconstitucionales, de concesiones unilaterales de condiciones más beneficiosas, y limitaría fuertemente el poder de dirección del empleador que emana del artículo $19 \mathrm{~N}^{\mathrm{o}}$ 21 de la Constitución (Irureta, 2006: 81). Este matiz permite concluir que el empleador goza de ciertos atributos directivos y organizativos que lo facultan para tomar ciertas decisiones que teóricamente pueden generar distinciones legítimas.

En el fondo, y siguiendo los derroteros que establece el artículo $19 \mathrm{~N}^{\circ} 16$ de la Constitución, el artículo 289, letra h), del Código del Trabajo considera lícitos, y por tanto no una extensión encubierta, las mejoras remuneracionales fundadas en la capacidad y la idoneidad del beneficiado. Estos factores permiten que el empleador pueda mejorar la posición contractual de un trabajador no afecto al instrumento colectivo, sobre bases objetivas y no simples caprichos del acreedor de trabajo ${ }^{50}$. En este orden de ideas, la capacidad es la aptitud o suficiencia para alguna cosa; la idoneidad, por su parte, se concibe como la calidad de idóneo, que se refiere a aquél que tiene buena disposición o suficiencia para una cosa. En ambos casos, se está haciendo referencia a requisitos vinculados al cargo o función, de forma tal que los requerimientos para un oficio u ocupación dependerán en alto grado de los requisitos de la oferta de empleo que haya realizado el empleador y la naturaleza misma del cargo.

Por último, habrá que tener presente que este criterio no es nuevo en la legislación laboral. El propio artículo $2^{\circ}$ del Código ya ha hecho referencia, desde antiguo, a la circunstancia de que las distinciones, exclusiones o preferencias basadas en las calificaciones exigidas para un empleo determinado no serán consideradas como actos de discriminación.

\subsection{Las comisiones bipartitas y los mecanismos de resolución de controversias}

La redacción planteada por el nuevo artículo 321 deja abierta la posibilidad de acordar distintas estipulaciones, de diverso orden, que se encuadren dentro de las materias propias de la negociación colectiva. El encabezado del artículo antes mencionado no deja lugar a dudas a este respecto, pues de manera expresa señala que las menciones a que se refiere la norma tienen el carácter de mínimas ("a lo menos"), permitiendo de este modo una amplia gama de alternativas que se ajusten a la autonomía colectiva.

A pesar de ello, la reforma incorporó un inciso según el cual el instrumento colectivo, adicionalmente, podrá contener la constitución de una comisión bipartita para la implementación y seguimiento del cumplimiento del instrumento colectivo o mecanismos de resolución de las controversias. Las comisiones son órganos de composición mixta, y cuya finalidad principal es la de vigilar la implementación del instrumento colectivo de acuerdo a las facultades que las partes negociadora han señalado (Cavas Martínez, 2007: 116). En la práctica laboral, este tipo de comisiones son de usual ocurrencia y su objetivo fundamental consiste en detectar incumplimientos a fin de evitar una judicialización innecesaria.

La reforma laboral ha radicado la irrupción de estas comisiones en un acuerdo de parte, facultativo, y no en decisiones de la autoridad administrativa (como ocurre en otras experiencias comparadas). Básicamente, la función de este tipo de comisiones será

\footnotetext{
${ }^{50}$ Para una simetría entre el vocablo arbitrario y caprichoso, vid., sentencia de la CORTE SUPREMA de 24 de septiembre de 2003. Gaceta Jurídica No 279 (2003), pp. 71 y siguientes; y sentencia de la CORTE DE APELACIONES DE SANTIAGO de 20 de junio de 2002. Gaceta Jurídica No 267 (2002), pp. 31 y siguientes.
} 
la de evitar la producción de conflictos, aclarando o estableciendo la inteligencia de una determinada cláusula del instrumento colectivo o bien resolviendo problemas puntuales de aplicación. No obstante, estas comisiones no pueden ser vistas como una especie de órgano jurisdiccional destinado a resolver controversias (Cabanellas, 1989: 281), ya que el legislador ha planteado esta fórmula como una clara alternativa de anticipación a conflictos mayores.

Dada la forma en que la nueva legislación incorpora a este tipo de comisiones, todo indica que la creación de comisiones bipartitas de seguimiento se encuadra dentro del contenido normativo formal del instrumento colectivo. Su objetivo primordial no es otro que lograr una eficaz aplicación de las condiciones de trabajo negociadas (Cavas Martínez, 2007: 118), y no mantener una negociación permanente de las distintas cláusulas o de otras materias que la comisión estime del caso abordar.

Conjuntamente con la hipotética creación de comisiones bipartitas, el legislador ha permitido que el instrumento colectivo acordado por las partes consagre mecanismos de resolución de las controversias. En este caso en particular, la nueva legislación hace referencia a mecanismos no jurisdiccionales, ya que de conformidad con la norma de la letra a), del artículo 420 del Código del Trabajo, los juzgados de letras del trabajo son competentes para conocer de la interpretación y aplicación de los contratos colectivos de trabajo o de las convenciones y fallos arbitrales en materia laboral. En este ámbito, los mecanismos más usuales estarán dados por la designación de un árbitro o mediador, o bien por el reconocimiento de instancias de conciliación.

Con todo, habrá que reconocer que esta orientación legislativa no es nueva. La jurisprudencia anterior a la reforma ya había reconocido que el contenido que la ley le asignaba al contrato colectivo no impedía que las partes pactaran otros mecanismos $\mathrm{u}$ obligaciones: "El contrato colectivo, además de su contenido fundamental, de carácter normativo, tendiente a establecer las condiciones comunes de trabajo y remuneración por un tiempo determinado, puede también contemplar otros contenidos, otras obligaciones o derechos entre las partes, como se desprende del artículo 345 del Código del Trabajo, que dispone, en sus números $1^{\circ}$ a $3^{\circ}$, las menciones que 'a lo menos' debe contener el contrato colectivo. Es lo que ocurre, en la especie, con cláusulas relativas a "bono de aceptación de oferta", pactado por única vez, y a "bono y anticipo especial de remuneraciones por vigencia a tres años", en vez de los dos que señala el Código, del contrato colectivo vigente en la empresa demandada, que no han tenido por finalidad establecer condiciones comunes de trabajo y de remuneraciones por un tiempo determinado, obligaciones de carácter único e instantáneo, oportunamente solucionadas por la empresa, por lo que no resulta procedente que puedan integrar un nuevo contrato colectivo y cumplirse por segunda vez, haciendo uso del derecho establecido en el inciso segundo del artículo 369 del Código del Trabajo" 51.

\section{Los efectos subjetivos del instrumento colectivo}

Siguiendo la misma lógica que se observaba en la legislación reformada, la Ley $\mathrm{N}^{\circ} 20.940$ ratifica un criterio que tiene respaldo constitucional: un trabajador podrá afiliarse y desafiliarse libremente de cualquier sindicato. Desde esta perspectiva, se intenta reafirmar el principio de la libre incorporación sindical, sin que existan estímulos indebidos a los procesos de ingreso o salida de un sindicato.

A pesar de lo anterior, la práctica laboral ha venido observando desde antiguo los efectos que se provocan con la desvinculación sindical de trabajadores que formaban

\footnotetext{
${ }^{51}$ Vid. sentencia de la CORTE SUPREMA de 22 de agosto de 2000. Revista de Derecho y Jurisprudencia y Gaceta de los Tribunales, Tomo XCVII, sección tercera (2000), pp. 157 y 158.
} 
parte de la nómina de personas afectas a un instrumento colectivo. Para resolver esta disyuntiva, la nueva normativa insiste en la tesis de que el cambio de afiliación sindical o desafiliación, mantendrá al trabajador afecto "al instrumento colectivo negociado por el sindicato al que pertenecía y que estuviere vigente, debiendo pagar el total de la cuota mensual ordinaria de ese sindicato durante toda la vigencia de dicho instrumento colectivo" 52 . Lo que se pretende evitar con este tipo de normas es la incorporación ocasional para el sólo efecto de obtener determinados beneficios, sin soportar en el tiempo el costo de la contribución al financiamiento del sindicato.

Por ello, y manteniendo la lógica de la libertad de afiliación o de desafiliación, el ordenamiento jurídico exige que el instrumento colectivo siga afectando al trabajador que participó en la respectiva negociación (pagando, por cierto, el $100 \%$ de la cuota sindical $)^{53}$. Una vez terminada la vigencia de dicho instrumento, el trabajador pasará a estar afecto al instrumento colectivo del sindicato al que eventualmente se hubiere afiliado, de existir este.

\section{La ultraactividad del instrumento colectivo}

Ocupando por única vez el término, el artículo 325 de la Ley $N^{\circ} 20.940$ se hace cargo de la figura de la ultraactividad de un instrumento colectivo ${ }^{54}$. Esta expresión hace referencia básicamente a la posibilidad de que el instrumento en cuestión siga produciendo efectos más allá de su vigencia.

\footnotetext{
${ }^{52}$ Artículo 323 de la Ley $\mathrm{N}^{\circ} 20.940$.

${ }^{53}$ Este criterio siempre contó con un numeroso apoyo jurisprudencial y doctrinario. Ejemplo de ello puede observarse en los siguientes antecedentes: "por generales que sean las estipulaciones contenidas en un contrato colectivo de trabajo, debe entenderse que ellas son aplicables a quienes estaban ligados por sus cláusulas y no a las personas ajenas a ellas" (sentencia de la CORTE DE APELACIONES DE SAN MIGUEL de 14 de octubre de 1988. Gaceta Jurídica $\mathrm{N}^{\mathrm{o}} 101$ [1988], pp. 110 y siguientes); “(...) las estipulaciones de los contratos colectivos sólo rigen respecto de los trabajadores que hayan sido parte de la negociación. Cualquier cláusula en contrario es nula de nulidad absoluta" (sentencia de la CORTE DE APELACIONES DE CONCEPCION de 30 de julio de 1990. Gaceta Jurídica No 127 [1990], pp. 105 y siguientes); "Por generales que sean las estipulaciones contenidas en un contrato colectivo de trabajo, debe entenderse que ellas son aplicables a quienes estaban ligados por sus cláusulas y no a las personas ajenas a ellas, como lo era el actor al momento de interponer su acción" (sentencia de la CORTE SUPREMA de 14 de octubre de 1988. Rol ํ3 313-88. En Repertorio de Legislación y Jurisprudencia Chilenas. Código del Trabajo y Leyes Complementarias, Tomo II. Editorial Jurídica de Chile, segunda edición, Santiago 2002, p. 88); “(...) los efectos del instrumento colectivo se radican exclusivamente en los trabajadores que formaron parte del grupo negociador al momento de iniciarse el proceso de negociación colectiva, si ésta es formal. Si el proceso ha sido llevado a cabo por el sindicato, produce efectos solamente para aquellos trabajadores que son socios de éste al momento de iniciarse el proceso de negociación colectiva y que figuran en la nómina correspondiente. (...). Cuando se trata de una negociación colectiva realizada por la vía de una comisión negociadora, el instrumento colectivo producirá efectos solamente en aquellos trabajadores representados por la comisión negociadora y que hubieren firmado el contrato colectivo respectivo. (...). El sentido normativo restrictivo del instrumento colectivo chileno, significa que éste puede extenderse a otros trabajadores exclusivamente por la sola voluntad empresarial (...)" (Vid. WALKER ERRAZURIZ, Francisco, Derecho de las Relaciones Laborales. Editorial Universitaria, Santiago, 2003, pp. 622 у 623); у “(...) los efectos del contrato colectivo alcanzan exclusivamente a las partes que lo celebran (...)" (Vid. THAYER ARTEAGA y NOVOA FUENZALIDA, cit., p. 483).

${ }^{54}$ Una crítica al uso de esta terminología puede consultarse en OGALDE MUÑOZ, Jorge, "Ultra actividad del instrumento colectivo en la reforma laboral". XXII Jornadas Nacional de la Sociedad Chilena de Derecho del Trabajo y de la Seguridad Social. Análisis crítico de la reforma al sistema de relaciones sindicales en Chile. En http://web.derecho.uchile.cl/documentos/LIBRO-JORNADAS-DERECHO-DELTRABAJO.pdf, p. 71.
} 
Asumiendo esta circunstancia, el artículo 325 indica que una vez extinguido el instrumento colectivo, "sus cláusulas subsistirán como integrantes de los contratos individuales de los respectivos trabajadores afectos, salvo las que se refieren a la reajustabilidad pactada tanto de las remuneraciones como de los demás beneficios convenidos en dinero, los incrementos reales pactados, así como los derechos y obligaciones que sólo pueden ejercerse o cumplirse colectivamente y los pactos sobre condiciones especiales de trabajo". Se trata de una norma imperativa, que exige la aplicación posterior de un instrumento colectivo por el solo ministerio de la ley, sin que se requiera acuerdo previo de las partes (Lizama Portal, 2016: 124). Y sus exclusiones, se justifican en la medida que el legislador pretende que materias tales como la reajustibilidad y los pactos especiales sean materia de negociación expresa (Thayer, 1991: 195) (Gamonal Contreras, 2007: 357) ${ }^{55}$.

La extinción de un instrumento colectivo implica, básicamente, que a la fecha de su vencimiento éste no ha sido reemplazado por otro instrumento de análoga naturaleza. Es decir, al reemplazarse un instrumento colectivo por otro que le sigue en el tiempo, entonces el nuevo instrumento reemplaza íntegramente las cláusulas contenidas en el primero. Desde esta perspectiva, no resulta factible exigir que aquellas cláusulas no contenidas en el nuevo instrumento se incorporen en los contratos individuales. Por tanto, la ultraactividad opera en el entendido que el instrumento colectivo que se extinguió no es reemplazado por uno nuevo.

La ultraactividad no es una figura nueva en la legislación laboral chilena. El antiguo artículo 348 del Código del Trabajo ya señalaba en su inciso segundo que una vez extinguido el contrato colectivo, "todos los derechos y obligaciones que se encuentran contenidos en él pasan a formar parte integrante de los contratos individuales de los trabajadores regidos por los mismos, efecto que se produce de pleno derecho, sólo con las excepciones anteriormente expresadas"56. Incluso, la jurisprudencia anterior a la reforma ya había señalado que los trabajadores a quienes se les hayan hecho extensivos los beneficios de un contrato colectivo anterior, y que no participaron de un nuevo proceso, los beneficios extendidos con anterioridad debían entenderse incorporados en el contrato individual de aquellos trabajadores. "Sin embargo, lo que se anota, en caso alguno puede significar que los trabajadores que actuaron en calidad de adherentes o a quienes se les extendieron los beneficios del contrato suscrito con anterioridad y que no participan del nuevo proceso sólo se les

\footnotetext{
55 "La excepción relativa a las cláusulas de reajustabilidad se justifica ya que la determinación de este factor ha sido realizado por las partes en atención a la situación económica general y a la duración del contrato, por lo que no pareciera adecuado prorrogar su efecto por ley".

${ }^{56}$ Vid. sentencia de la CORTE DE APELACIONES DE CONCEPCION de 18 de junio de 2004. Revista de Derecho y Jurisprudencia y Gaceta de los Tribunales T. CII, sección tercera (2005), p. 357. Y agregó: "Hay una suerte de efecto sustitutivo automático, donde la vigencia de las normas colectivas incorporadas al contrato individual no depende de la vigencia del respectivo instrumento colectivo, ya que el inciso $2^{\circ}$ de la disposición legal citada dispone la ultraactividad de las normas colectivas incorporadas al contrato individual una vez cesada la vigencia del instrumento colectivo. Se ha dicho que el legislador ha creado una ficción legal en cuya virtud las cláusulas del instrumento colectivo se incorporan de pleno derecho, automáticamente, por el solo ministerio de la ley, al contrato individual, sin que sea necesaria su reproducción en este último". En igual sentido, vid. sentencia de la CORTE DE APELACIONES DE CONCEPCION de 27 de marzo de 2014 ( $\mathrm{N}^{\circ}$ de Ingreso Corte 411-2013): “10.- Que, de otro lado la eficacia normativa del contrato colectivo se caracteriza, además, por el efecto de ultraactividad que consiste en que una vez extinguido el contrato el legislador impone que las cláusulas normativas continúen en vigencia en los contratos individuales. Este efecto, también denominado 'efecto ultra termine' o 'efecto a posteriori' se encuentra consagrado en el artículo 348 inciso $2^{\circ}$ del Código del Trabajo, en cuanto establece que extinguido el contrato colectivo, sus cláusulas subsistirán como integrantes de los contratos individuales de los respectivos trabajadores, salvo excepciones”.
} 
mantendrán los beneficios pactados en sus contratos individuales, en espera de que su empleador decida hacer uso de la facultad contenida en el artículo 346 del Código Laboral, es decir, les extienda nuevamente los beneficios contenidos en el instrumento colectivo. Aceptar esto, lisa y llanamente significaría desconocer lo dispuesto en el artículo 348 (...). No puede quedar entregado al arbitrio o decisión unilateral del empleador la época en que quiera hacer extensivo el beneficio a algún trabajador que con anterioridad gozaba de un beneficio idéntico al contemplado en el nuevo instrumento" $" 57$.

\section{CONCLUSIONES}

Las principales conclusiones que se pueden extraer del presente artículo, a partir de las reflexiones formuladas en las páginas anteriores, son las siguientes:

1. De conformidad con las nuevas directrices de la reforma laboral introducida por la Ley $\mathrm{N}^{\circ} 20.940$ (de 2016), toda negociación colectiva regulada por el Código del Trabajo debe derivar en un instrumento colectivo. Se trata de una nueva categoría lingüística creada por el legislador, bajo la cual se estructura una tipología de alternativas representadas por el contrato colectivo, el convenio colectivo, el fallo arbitral y el acuerdo del grupo negociador. Sólo estas figuras, rigurosamente señaladas por el legislador, tienen el carácter de instrumento colectivo.

2. El instrumento colectivo se presenta en la nueva normativa como un concepto amplio y genérico, omnicomprensivo de distintas alternativas negociadoras. En razón de este carácter, la Ley $\mathrm{N}^{\circ} 20.940$ exige que todo instrumento colectivo cumpla con una serie de exigencias homogéneas y predicables de cada uno de ellos. Más aun, entre el instrumento colectivo y las demás figuras contractuales que se derivan de la negociación colectiva, se establece una relación de género a especie.

3. La mayor parte de la jurisprudencia y la dogmática han concluido que, todo instrumento colectivo tiene carácter solemne. Para arribar a dicha conclusión, se amparan fundamentalmente en la exigencia de escrituración y registro que la reforma laboral exige para cualquiera de estos instrumentos.

4. Por expresa disposición legal, el acuerdo del grupo negociador constituye una categoría más de instrumento colectivo. No obstante, carece de regulación legal. Frente a esta omisión, existen tres alternativas: (i) Concluir que, al no existir normativa, los grupos negociadores no se encuentran habilitados para participar en un proceso negociador (cuestión que chocaría con las conclusiones a las que arribó el STCo. de 09 de mayo de 2016); (ii) Aplicarle al acuerdo del grupo negociador las normas de la negociación colectiva reglada. No obstante, no existe ninguna norma de reenvío que permita una conclusión de esta naturaleza; sin perjuicio que en el Título IV, Libro IV, del Código, existen normas que están diseñadas exclusivamente para una organización sindical (y no para un grupo negociador); (iii) $\mathrm{O}$ bien, concluir que la negociación colectiva de los grupos transitorios de trabajadores se puede llevar a cabo con total

\footnotetext{
${ }^{57}$ Vid. sentencia de la CORTE DE APELACIONES DE CONCEPCION de 18 de junio de 2004. Revista de Derecho y Jurisprudencia y Gaceta de los Tribunales T. CII, sección tercera (2005), p. 357.
} 
desregulación. Esto último contraría el espíritu que tuvo el legislador al momento de dictar la Ley $\mathrm{N}^{\circ} 20.940$, y provocaría una evidente asimetría en relación con la negociación colectiva llevada a cabo por una organización sindical. En este escenario, la única alternativa viable es que la jurisprudencia, o eventualmente el legislador, resuelvan estas omisiones en lo que respecta a la negociación colectiva de las coaliciones transitorias de trabajadores.

5. La reforma laboral ha ampliado el ámbito regulatorio del instrumento colectivo. Si bien es cierto que este tipo de instrumento deberá contener normas sobre remuneraciones, beneficios y condiciones de trabajo; también es efectivo que la legislación ha permitido que en el mismo instrumento se contenga todo tipo de estipulaciones debidamente acordadas, siempre y cuando se encuentren especificadas. En este orden de ideas, el nuevo Código abre las alternativas de los negociadores y les permite incorporar otro tipo de estipulaciones distintas de lo meramente remuneracional o de los beneficios y condiciones de trabajo. Y ello se armoniza con las exigencias que la propia OIT ha indicado en su Convenio $\mathrm{N}^{\mathrm{o}} 154$.

\section{BIBLIOGRAFIA}

ALONSO OLEA, Manuel, (1982). Las fuentes del Derecho, en especial del Derecho del Trabajo según la Constitución. Civitas, Madrid.

ALONSO OLEA, Manuel, CASAS BAHAMONDE, María Emilia, (2009). Derecho del Trabajo. Civitas, vigésimo sexta edición revisada, Madrid.

ARELLANO ORTIZ, Pablo, LIENDO ROA, Ricardo, y WALKER ERRAZURIZ, Francisco, (2016). Reforma Laboral Ley $N^{\circ}$ 20.940. Librotecnia, Santiago.

AYLWIN CHIORRINI, Andrés, "El sistema normativo de negociación colectiva: características y reforma laboral". En XXII Jornadas Nacional de la Sociedad Chilena de Derecho del Trabajo y de la Seguridad Social. Análisis crítico de la reforma al sistema de relaciones sindicales en Chile. En http://web.derecho.uchile.cl/documentos/LIBRO-JORNADAS-DERECHO-DELTRABAJO.pdf.

BIBLIOTECA DEL CONGRESO NACIONAL DE CHILE, Historia de la Ley $N^{o}$ 20.940. Segundo trámite constitucional en el Senado. En www.bcn.cl

BIBLIOTECA DEL CONGRESO NACIONAL DE CHILE, Historia de la Ley $N^{o}$ 19.069. En www.bcn.cl

BIBLIOTECA DEL CONGRESO NACIONAL, Historia de la Ley $N^{o}$ 19.759. Segundo Informe de la Comisión de Trabajo y Previsión Social. Diario de Sesiones del Senado, sesión $8^{\mathrm{a}}$, especial, de 20 de junio de 2001. En www.ben.cl

CABANELLAS, Guillermo, (1989). Tratado de Derecho Laboral, T.III, Vol. 3. Heliasta, tercera edición, Buenos Aires.

CASCAJO CASTRO, José Luis, (1988). La tutela constitucional de los derechos sociales. Centro de Estudios Constitucionales, Madrid.

CAVAS MARTINEZ, Faustino, (2007). "Las comisiones paritarias y la solución de los conflictos laborales derivados de la interpretación y aplicación del convenio colectivo". Revista del Ministerio del Trabajo y Asuntos Sociales No 68.

DESPAX, Michel, (1989). Négociations, conventions et accords collectifs. Droit du Traval. Dirección de G. H. Camerlynck. Dalloz, Paris. 
GAMONAL CONTRERAS, Sergio, (2007). Derecho Colectivo del Trabajo. LexisNexis, Santiago.

GARCIA VIÑA, Jordi, (2013). Derecho Sindical. Juruá, segunda edición, Lisboa.

GOERLICH PESET, José María, (2013). "Contenido mínimo del convenio colectivo". El sistema de negociación colectiva en España. Dirección de José Luis Monereo Pérez, y María Nieves Moreno Vida. Thomson Reuters/Aranzadi, Pamplona.

GONZÁLEZ ORTEGA, Santiago, (2004). "Vigencia y ultraactividad de los convenios colectivos". Temas Laborales $\mathrm{N}^{\circ} 76$.

GONZÁLEZ ORTEGA, Santiago, (2013). "La comisión paritaria del convenio colectivo". Temas Laborales $\mathrm{N}^{\circ} 120$.

HALPERN MONTECINO, Cecily, (1992). "Extensión de beneficios colectivos: La aplicación jurisprudencial del artículo 122 de la Ley $\mathrm{N}^{\mathrm{o}} 19.069$ y su posible efecto perverso". Revista Laboral Chilena $\mathrm{N}^{\mathrm{o}} 10$.

IRURETA URIARTE, Pedro, (2006). Constitución y Orden Público Laboral. Un análisis del art. $19 \mathrm{~N}^{\circ} 16$ de la Constitución chilena. Colección de Investigaciones Jurídicas $\mathrm{N}^{\circ}$ 9. Universidad Alberto Hurtado.

LIZAMA PORTAL, Luis, (2016). La reforma laboral explicada y comentada. Ediciones Luis Lizama Portal \& Cía. Abogados, Santiago.

LOPEZ SANTA MARÍA, Jorge, (1986). Los Contratos. Parte General. Editorial Jurídica de Chile, Santiago, 1986.

MACCHIAVELLO CONTRERAS, Guido, (1989). Derecho Colectivo del Trabajo. Editorial Jurídica de Chile, Santiago.

MARTINEZ ROCAMORA, Luis G., (1998). Decisiones empresariales y principio de igualdad. Cedecs, Barcelona.

MONEREO PEREZ, José Luis, y TOMAS JIMÉNEZ, Natalia, (2013). "E1 reconocimiento internacional y europeo del derecho a la negociación colectiva". El sistema de negociación colectiva en España. Dirección de José Luis Monereo Pérez y María Nieves Moreno Vida. Thomson Reuters/Aranzadi, Pamplona 2013.

MONTOYA MELGAR, Alfredo, (2008). Derecho del Trabajo. Tecnos, vigésima novena edición, Madrid.

OGALDE MUÑOZ, Jorge, "Ultra actividad del instrumento colectivo en la reforma laboral". XXII Jornadas Nacional de la Sociedad Chilena de Derecho del Trabajo y de la Seguridad Social. Análisis crítico de la reforma al sistema de relaciones sindicales en Chile. En http://web.derecho.uchile.cl/documentos/LIBROJORNADAS-DERECHO-DEL-TRABAJO.pdf.

PALOMEQUE LOPEZ, Manuel Carlos, (2004). "El derecho constitucional de igualdad en las relaciones de trabajo". En Derecho del Trabajo y Razón Crítica. Libro dedicado al profesor M. C. Palomeque en su XXV aniversario como catedrático, Salamanca.

PALOMEQUE LOPEZ, Manuel Carlos, y ALVAREZ DE LA ROSA, Manuel, (1995). Derecho del Trabajo. Centro de Estudios Ramón Areces, tercera edición, Madrid.

PERSIANI, Mattia, (2016). Diritto Sindicale. Wolters Kluwer-Cedam, décimo sexta edición, Padua.

RAMACIOTTI FRACCHIA, José Luis, (1992). "Extensión de beneficios a trabajadores que no negociaron colectivamente". Revista Laboral Chilena $\mathrm{N}^{\circ} 2$.

REPERTORIO DE LEGISLACIÓN Y JURISPRUDENCIA CHILENAS. CÓDIGO DEL TRABAJO Y LEYES COMPLEMENTARIAS, (2002). Tomo II. Editorial Jurídica de Chile, segunda edición, Santiago.

RODRIGUEZ-PIÑERO Y BRAVO-FERRER. Miguel, y FERNANDEZ LOPEZ, María Fernanda, (1986). Igualdad y Discriminación. Tecnos, Madrid. 
ROJAS MIÑO, Irene, (2014). "La negociación colectiva en Chile: la legal y la general". En La negociación colectiva en Chile. Coordinación de Irene Rojas Miño. Librotecnia, Santiago.

ROJAS MIÑO, Irene, (2007). "Las reformas laborales al modelo normativo de negociación colectiva del Plan Laboral”. Ius et Praxis Año $13 \mathrm{~N}^{\circ} 2$.

SEMPERE NAVARRO, Antonio-Vicente, (1983). "Las fuentes del Derecho del Trabajo". En La obra cientifica de Manuel Alonso Olea (en sus XXV años de catedrático de Derecho del Trabajo). Servicio de Publicaciones Universidad de Murcia, Murcia.

STARCK, Christian, "Derechos Fundamentales y Derecho Privado", (2002). Revista Española de Derecho Constitucional No 66, Año 22.

THAYER ARTEGA, Sindicatos y negociación colectiva, (1991). Editorial Jurídica de Chile, Santiago.

THAYER ARTEAGA, William, y NOVOA FUENZALIDA, Patricio, (1987). Manual de Derecho del Trabajo, Tomo I. Editorial Jurídica de Chile, Santiago.

WALKER ERRAZURIZ, Francisco, (2003). Derecho de las Relaciones Laborales. Editorial Universitaria, Santiago.

YAÑEZ MONJE, Eduardo, (2013). "Unifica jurisprudencia en el sentido que 'los permisos sindicales', en tanto se pretendan regulados de manera distinta -superior- a la establecida por la ley, deben corresponder, o ser producto de una negociación que conste por escrito' (Excma. Corte Suprema, Rol No 4.187-2013, de 14 de octubre de 2013)". Revista Chilena de Derecho del Trabajo Vol. 4, N 8. 